\title{
Study on the adaptability of some blueberry cultivars in the Republic of Moldova
}

\author{
P. Sava ${ }^{*}$ and C. Caterenciuc ${ }^{1}$ \\ 1Scientific and Practical Institute of Horticulture and Food Technologies, \\ Republic of Moldova
}

*Corresponding author email: psava2110@gmail.com

\begin{abstract}
The paper is a scientific analysis of research conducted during the years 20152018 in the Central Area of the Republic of Moldova on the adaptability of some blueberry cultivars ('Blueray', 'Earliblue', 'Azur', 'Lax'), studying the key factors that must be known and performed to obtain a culture successfully, with quality fruit. As a result of research and observations on the factors influencing plant development, the duration of the phenological phases, the content and quantity of nutrients in fruit on the studied blueberry cultivars, it was established that: climatic conditions are favorable $_{\bar{j}}$ if the requirements of this species are met, in particular, planting in the acid substrate (peat with pH 4.5-5.5). Cultivated of cultivars show high resistance to frost, disease and pests, but require irrigation in dry periods. The climatic conditions in the study years influence the vegetation stages of the studied blueberry cultivars, these being between which varies between 15 to $23^{\text {rd }}$ March, flowering between 17 to $26^{\text {th }}$ April and fruit ripening between 25 May and $6^{\text {th }}$ June month. Also, the climatic conditions influenced the quality of the fruits for the analyzed cultivars, the soluble dry matter varied between 10.12\%-15.04\%; of sugars between 3.40-15.04\%; tannins and coloring substances between 15.04-24.94 mg\%; vitamin $C$ between 10.60-19.80 mg\%; sugar/acid ratio between 1.20-9.29.
\end{abstract}

Keywords: phenophases, blueberry fruits, qualitative indicators, cultivars, year conditions.

\section{INTRODUCTION}

Blueberries are increasingly consumed in Europe, are known for their contribution to maintaining health. They are known as an excellent source of vitamins and other bioactive substances of pharmaceutical interest, being one of the richest sources of ascorbic acid 1-10 $\mathrm{mg} / 100 \mathrm{~g}$ fresh substance. Compared to raspberry and blackberry fruits, the anthocyanins content of blueberries is much higher and can vary between 146-2,199 mg/100 g of fresh substance (Asănică, 2017). The fruits and leaves of this shrub have a content similar to that of the mountain blueberry (Vaccinium myrtillus), having in addition to its nutritional role and medicinal properties. Thus, the blueberry fruits are rich in soluble dry matter.

Biochemical (sugars, acids, dry matter), vitamins, including vitamin C, vitamins A, B1, B2, E, mineral salts, anthocyanins with antioxidant action. The fruits are 2-4 times larger compared to mountain blueberries, with superior commercial qualities, and are highly sought after in European markets as fresh fruit mainly (Sumedrea et al., 2014). The productive potential of blueberries is about 3-5 kg of fruit on a bush aged 6-8 years, which corresponds to 3-4.5 t/ha, and the duration of a plantation is 20-25 years (Mladin Gh. and Mladin P., 1992). Blueberries are important primarily due to their fruits, which are 
especially valuable for both fresh consumption and industrialization in the form of juice, syrup, jam, jam, jelly, blueberry brandy, etc. (Gradinariu and Istrate, 2009). Blueberry is a species of cool and humid climate which, although it tolerates partial shade, gives the best results when it receives direct sunlight. It has moderate demands on temperature, succeeding in areas where the annual average is between 7.8 and $8.5^{\circ} \mathrm{C}\left(15-17^{\circ} \mathrm{C}\right.$ during the vegetation period), and during the rest period, it can withstand temperatures up to $-25^{\circ} \mathrm{C}$ (Mladin Gh. and Mladin P., 1992). The optimum temperatures for blueberries are between 18 and $30^{\circ} \mathrm{C}$, and the absolute minimum is $7^{\circ} \mathrm{C}$ and maximum $42^{\circ} \mathrm{C}$ (outside the range of absolute temperatures the growth stops). The plants are resistant to frost during the vegetative dormancy period, if the tissues of the stems and branches are well matured. The frost resistance during the rest period is relatively high, the critical limit being $-36^{\circ} \mathrm{C}$ (Sumedrea et al.,2014).

\section{MATERIAL AND METHOD}

The research was performed on the experimental field of the laboratory "Fruit bushes and strawberry" within IP ISPHTA. Four blueberry cultivars were taken as study objects: 'Blueray', 'Earliblue', 'Azur' and 'Lax', which were planted in 2010 in 10-liter buckets, filled with the acidic substrate with $\mathrm{pH}$ 4.5-5.5, and in 2018 they were replanted in 30-40 liter pots.

The study was performed by field and laboratory methods provided by the established program for fruit bushes. The studied blueberry cultivars were subject to observations and evidence on the stages of plant development, resistance to natural limiting factors.

The assessment of the frost resistance of the studied blueberry cultivars was made based on the grades, marking with grade 5 - completely resistant cultivar. Observations and records on the phenological stages of plant development of blueberry cultivars but also the indicators analyzed in the studied cultivars were made in 2015-2018.

The research was based on the monitoring of phenological, biometric and biochemical indicators. During the research period, all the studied blueberry cultivars did not observe the frost of the plants, due to the favorable climatic conditions during the winter.

Also, there were no symptoms of the attack of diseases and pests, which allowed the exclusion of chemical treatments. The analyzed data represent averages of 4 repetitions. The data obtained for biometric and biochemical indicators of blueberry were ensured statistically by calculating standard deviations (Cociu and Oprea, 1989).

\section{RESULTS AND DISCUSSIONS}

The results of the observations made during the phenological phases of the blueberry plants for the studied cultivars during the years 2015-2018 were included in Table 1.

According to the data in table 1 during the research it was established that the budding of blueberry cultivars included in the study begins between March 15-23, but the phenological phase of flowering depends on the climatic conditions established in the given period, the capacities of the studied and varies between April 17-26.

Depending on the climatic conditions of the year in 2016, the phenological phases took place at the earliest, and in 2017 - at the latest.

The average duration between the development phases of blueberry plants from the beginning of vegetation until the fruit ripening is 101 days. The ripening of blueberry fruits (Figure 2) takes place over 68 days after flowering and begins between June 21 to July $6^{\text {th }}$. 
Table 1. Phenological phases of development of blueberry plants

\begin{tabular}{|c|c|c|c|c|c|c|}
\hline \multirow{2}{*}{ Year } & \multicolumn{6}{|c|}{ Name of phenophases, duration between them, days } \\
\cline { 2 - 7 } & $\begin{array}{c}\text { Budding, } \\
\text { data } \\
\text { duration } \\
\text { between phases, } \\
\text { days }\end{array}$ & $\begin{array}{c}\text { Floweri } \\
\text { ng, data }\end{array}$ & $\begin{array}{c}\text { Average } \\
\text { duration } \\
\text { between } \\
\text { phases, days }\end{array}$ & $\begin{array}{c}\text { Fruit } \\
\text { ripening, } \\
\text { data }\end{array}$ & $\begin{array}{c}\text { Average } \\
\text { duration } \\
\text { between } \\
\text { phases, days }\end{array}$ \\
\hline 2015 & March 19 & 32 & April 20 & 66 & June25 & 98 \\
\hline 2016 & March 15 & 33 & April 17 & 65 & June 21 & 98 \\
\hline 2017 & March 23 & 34 & April 26 & 71 & July 6 & 105 \\
\hline 2018 & March 21 & 33 & April 23 & 69 & July 1 & 102 \\
\hline Mean & - & 33 & - & 68 & & 101 \\
\hline
\end{tabular}

The average duration of the period from budding to the flowering of blueberry plants is 33 days (Figure 1).

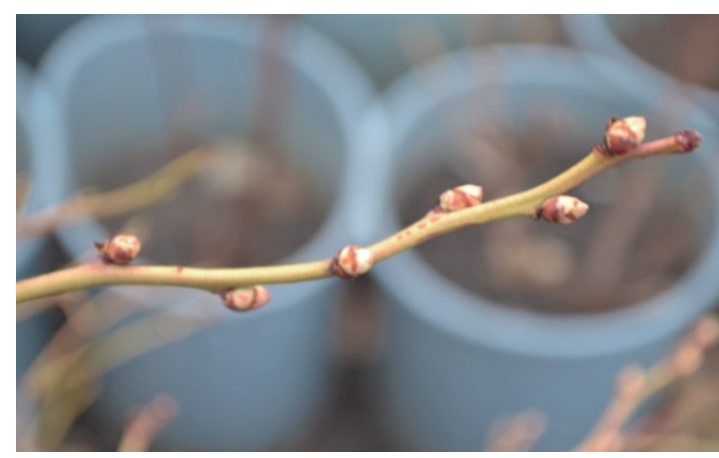

a

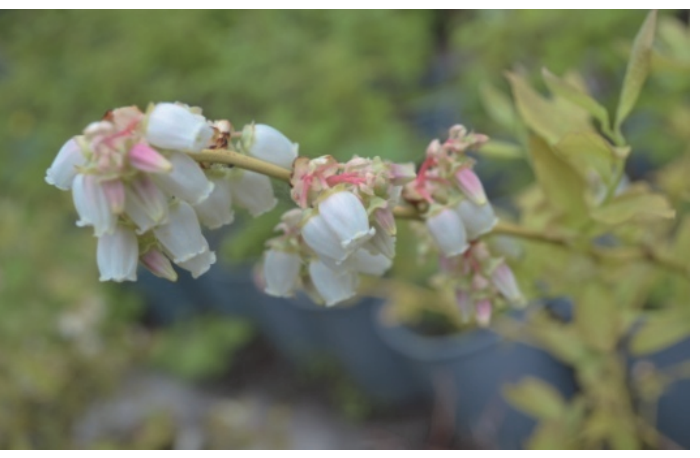

b

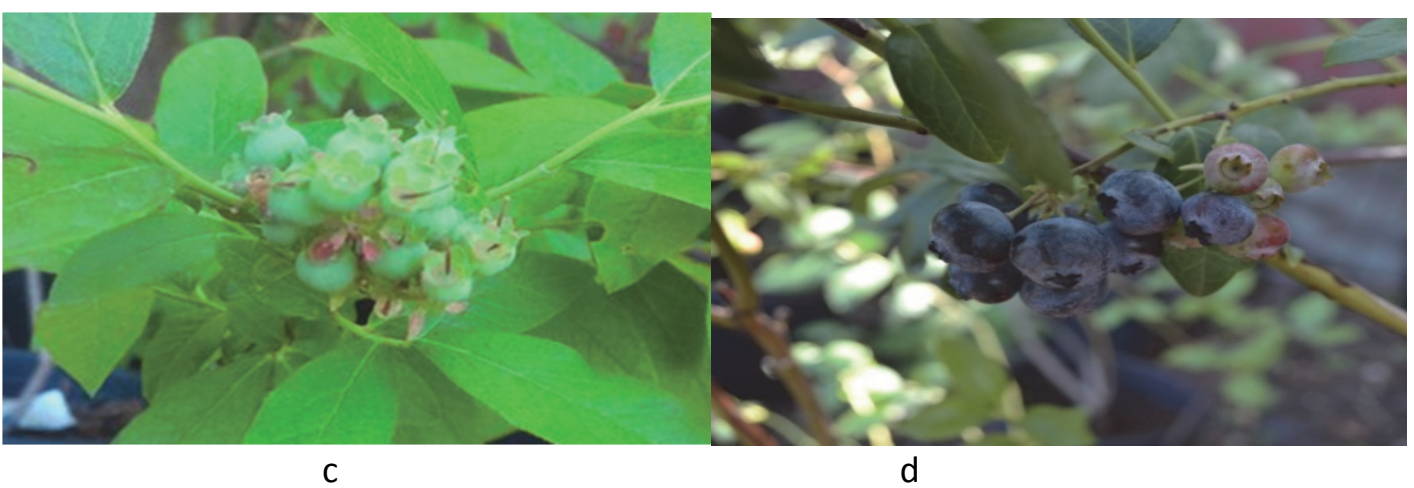

Figure 1. The phenophases of blueberry plants: a) budding

b) flowering, c) fruit formation, d) fruit maturation 

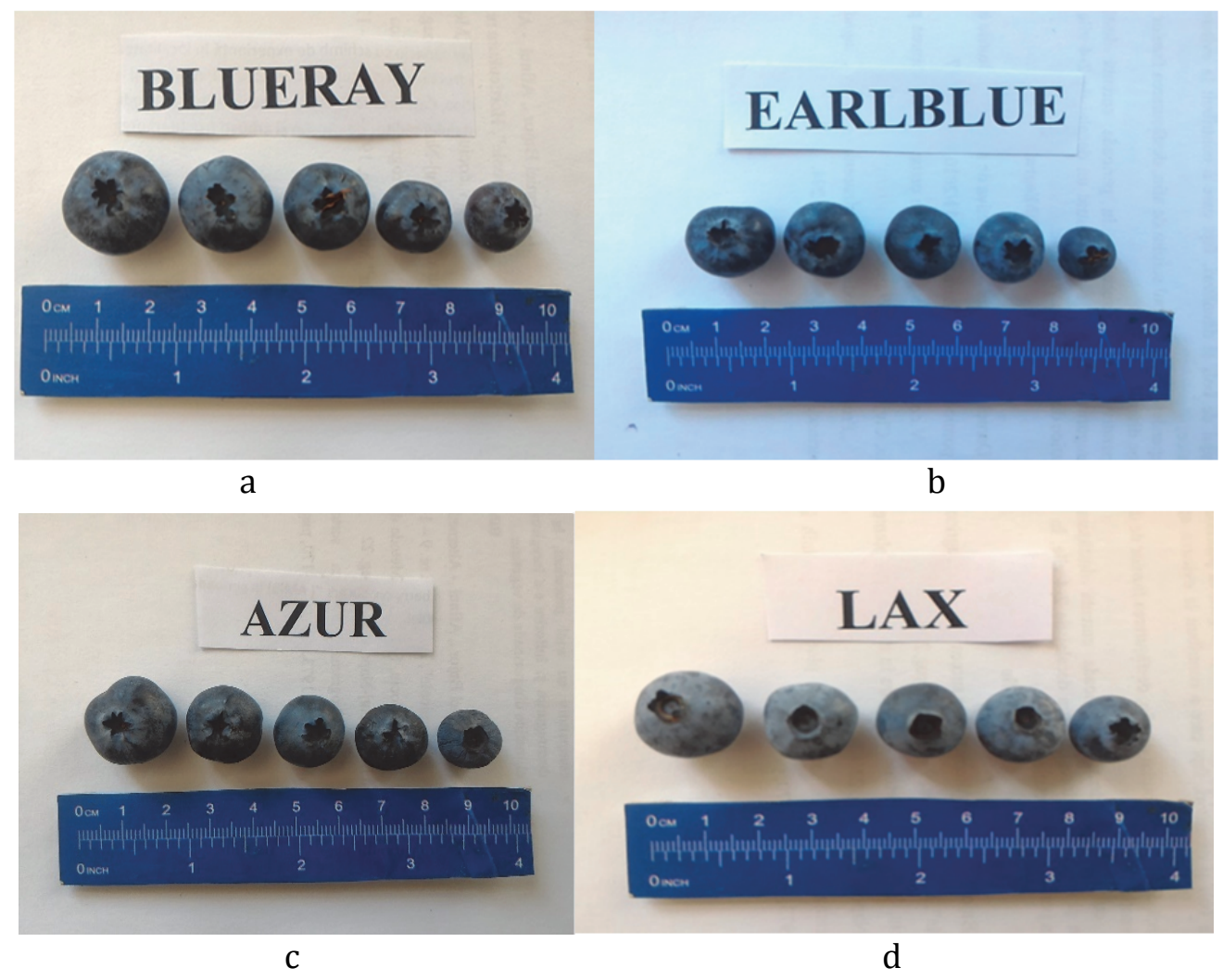

Figure 2. The ripe blueberry fruits of the studied: a) Blueray; b) Earliblue; c) Azur; d) Lax.

The research carried out to assess the quality of blueberry fruits by biochemical analysis allowed us to determine the content and quantity the main biometric and biochemical indicators on the cultivars studied depending on the conditions of the year, and the results were included in Table 2.

The results obtained and presented in Table 2 regarding the chemical composition of blueberries attest to the presence of dry substances, the content of which varied between $10.12 \%$ for the 'Blueray' cultivar in 2016 and $15.04 \%$ for the cultivar 'Earliblue' in 2015. The sugars in the fruit have varied from 3.40\% for the cultivar 'Lax' in 2017 to $7.74 \%$ for the 'Earliblue' in 2015. The established average of titrated fruit acidity varied from $0.9 \%$ for the 'Lax' cultivar in 2017 to 3,36\% for the 'Azur' cultivar in 2015. The presence of the average amount of tanning and coloring substances varied between $24.94 \mathrm{mg} \%$ for the 'Blueray' cultivar in 2015 to $62.29 \mathrm{mg} \%$ for the 'Lax' cultivar in 2016. The average content of vitamin $\mathrm{C}$ accumulated in blueberry fruits reached the lowest values of $10.6 \mathrm{mg} \%$ for the 'Blueray' cultivar in 2016, and the highest of $19.80 \mathrm{mg} \%$ for the 'Lax' cultivar in 2015. The standard deviation for biometric and biochemical indicators (Table 2). e.g.

The ratio between the content of sugar and acid in blueberry fruits is expressed by the sugar/acid ratio. With the increase of the values at the sugar/acid coefficient, the quality of the fruit also increases. The sugar/acid coefficient established for the studied blueberry cultivars varied from 1.2 for the 'Azur' in 2015 and the 'Earliblue' cultivars in 2018 to 9.29 for the 'Blueray' cultivar in 2015.

The average values on the four years of study regarding the quality indicators of the studied blueberry ('Blueray', 'Earliblue', 'Azur', 'Lax') are presented in Figure 3. 
Table 2. Results on qualitative indicators on the analyzed cultivars, depending on the study year

\begin{tabular}{|c|c|c|c|c|c|c|}
\hline $\begin{array}{c}\text { Cultivar/ } \\
\text { year }\end{array}$ & $\begin{array}{c}\text { Dry } \\
\text { substances } \\
\%\end{array}$ & $\begin{array}{c}\text { The sugar } \\
\text { content } \\
\%\end{array}$ & $\begin{array}{c}\text { Acidity } \\
\%\end{array}$ & $\begin{array}{l}\text { Tanning and } \\
\text { coloring } \\
\text { substances, \% }\end{array}$ & $\begin{array}{l}\text { Vitamin } \\
\text { C, } \\
\mathrm{mg} \% \\
\end{array}$ & $\begin{array}{l}\text { Coefficient } \\
\text { sugar/acid }\end{array}$ \\
\hline 'Bluer & & & & & & \\
\hline 2015 & $.07 \pm 2.47$ & $13.0 \pm 5.84$ & $1.40 \pm 0.63$ & $24.94 \pm 11.09$ & $16.94 \pm 2.35$ & $9.29 \pm 5.02$ \\
\hline 2016 & $.12 \pm 1.48$ & $5.58 \pm 1.58$ & $1.60 \pm 0.43$ & $41.57 \pm 36.03$ & $10.60 \pm 3.99$ & 0.77 \\
\hline 2017 & $0.60 \pm 1.0$ & $6.20 \pm 0.96$ & $2.08 \pm 0.05$ & - & $13.20 \pm 1.39$ & 1.29 \\
\hline 2018 & - & $3.85 \pm 3.31$ & $3.03 \pm 1.0$ & $41.57 \pm 36.03$ & $17.60 \pm 3.01$ & 2.97 \\
\hline $\begin{array}{l}\text { Variation } \\
\text { limit }\end{array}$ & $\begin{array}{l}6- \\
07 \pm 4.10\end{array}$ & $\begin{array}{c}3.85- \\
13,0 \pm 9.15\end{array}$ & $\begin{array}{c}1.4- \\
3.03 \pm 1.63 \\
\end{array}$ & $\begin{array}{r}24 . \\
41.57 \\
\end{array}$ & $\begin{array}{c}10.6- \\
17.6 \pm 7.0\end{array}$ & $\begin{array}{r}1 . \\
9.29\end{array}$ \\
\hline 'Earliblue' & & & & & & \\
\hline 2015 & $.04 \pm 2.24$ & $7.74 \pm 1.55$ & $1.40 \pm 0.8$ & $35.25 \pm 2.66$ & $12.12 \pm 1.59$ & $1.24 \pm 0.9$ \\
\hline 2016 & $.56 \pm 2.24$ & $7.20 \pm 1.01$ & $2.18 \pm 0.02$ & 37.41 & $8.92 \pm 5.21$ & 1.16 \\
\hline 2017 & - & $6.10 \pm 0.09$ & $2.20 \pm 0$ & 45.7 & $12.80 \pm 0.91$ & 0.66 \\
\hline 2018 & - & $3.72 \pm 2.47$ & $.03 \pm 0.83$ & 33.2 & $11.00 \pm 3.71$ & 0.94 \\
\hline $\begin{array}{l}\text { Variation } \\
\text { limit }\end{array}$ & $\begin{array}{l}10.56- \\
.04 \pm 4.48\end{array}$ & $\begin{array}{c}3.72- \\
7.74 \pm 4.02\end{array}$ & $\begin{array}{c}1.4- \\
3.03 \pm 1.63\end{array}$ & $\begin{array}{r}33.2 \\
\pm 1 \\
\end{array}$ & $\begin{array}{c}11.0- \\
18.92 \pm 8.92 \\
\end{array}$ & - \\
\hline 'Azur' & & & & & & \\
\hline 2015 & $36 \pm 1.13$ & $6.45 \pm 0.03$ & $3.36 \pm 0.59$ & $41.57 \pm 3.12$ & $11.44 \pm 4.95$ & 1.05 \\
\hline 2016 & - & $7.20 \pm 0.72$ & $2.18 \pm 0.59$ & 37. & $18.92 \pm 2.53$ & 1.05 \\
\hline 2017 & $60 \pm 1.13$ & $4.90 \pm 1.58$ & $2.80 \pm 0.03$ & 41. & $17.60 \pm 1.21$ & 0.45 \\
\hline 2018 & - & $7,36 \pm 0,88$ & $2.72 \pm 0.05$ & 58.18 & $17.60 \pm 1.21$ & $2.70 \pm 0.45$ \\
\hline $\begin{array}{l}\text { Variat } \\
\text { limit }\end{array}$ & $\begin{array}{l}10.60- \\
.86 \pm 2.26\end{array}$ & $\begin{array}{c}4.90- \\
7.36 \pm 2.46\end{array}$ & $\begin{array}{c}2.18- \\
3.36 \pm 1.18\end{array}$ & $\begin{array}{r}37 \\
58.18\end{array}$ & $\begin{array}{c}11.44- \\
18.92 \pm 7.48\end{array}$ & - \\
\hline 'Lax' & & & & & & \\
\hline 2015 & $60 \pm 1.75$ & $6.17 \pm 0.85$ & $2.45 \pm 0.22$ & $33.26 \pm$ & $19.80 \pm 0.94$ & $=0.03$ \\
\hline 2016 & $.10 \pm 1.75$ & $5.16 \pm 0.16$ & $2.28 \pm 0.05$ & 62.2 & $18.48 \pm 0.38$ & 0.29 \\
\hline 2017 & - & $3.40 \pm 1.92$ & $0.90 \pm 1.33$ & 45.7 & $18.26 \pm 0.60$ & 0.85 \\
\hline 2018 & - & $6.55 \pm 1.23$ & $3.27 \pm 1.04$ & 49.8 & $18.90 \pm 0.04$ & $2.00 \pm 0.55$ \\
\hline $\begin{array}{l}\text { Variati } \\
\text { limit }\end{array}$ & $\begin{array}{c}11.10- \\
14.60 \pm 3.50\end{array}$ & $\begin{array}{c}3.40- \\
6.55 \pm 3.15\end{array}$ & $\begin{array}{c}0.9- \\
3.27 \pm 2.37\end{array}$ & $\begin{array}{c}33.26- \\
62.29 \pm 29.03\end{array}$ & $\begin{array}{c}18.26- \\
19.80 \pm 1.54\end{array}$ & $\begin{array}{c}2.0- \\
3.4 \pm 1.4\end{array}$ \\
\hline
\end{tabular}

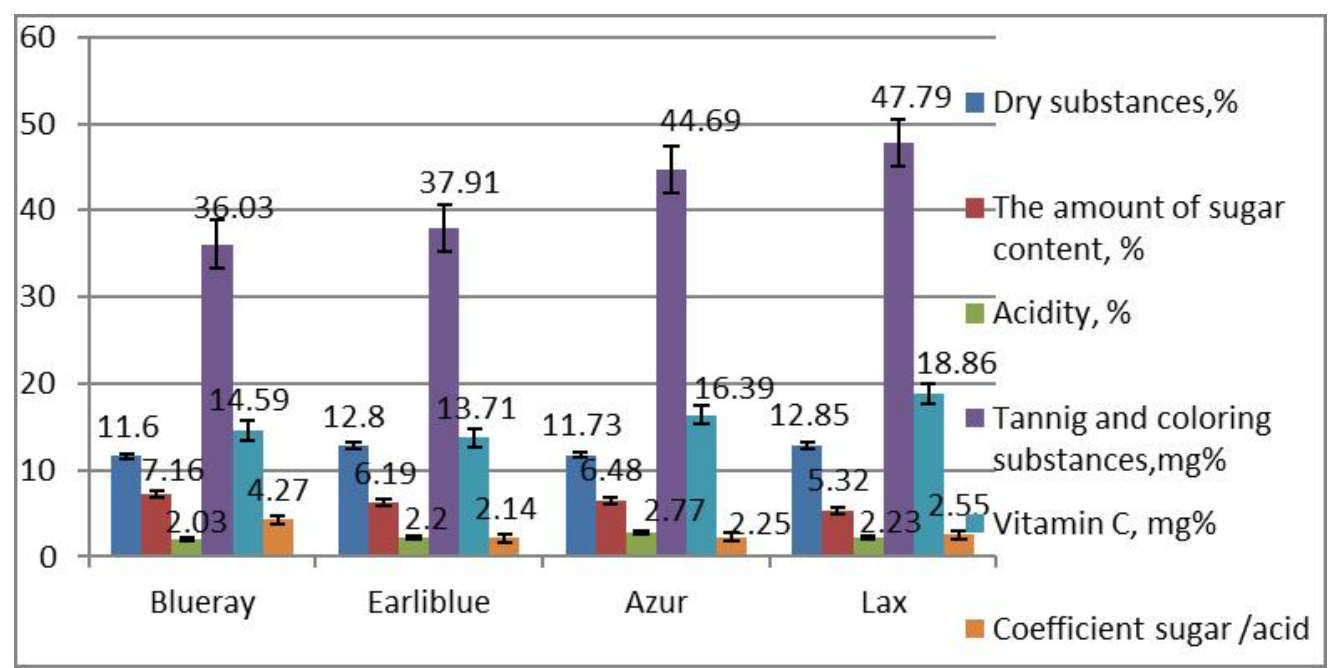

Figure 3. The average values of the accumulated quantity of nutrients of the studied blueberry during the years 2015-2018 - Vertical bars are indicating the standard deviation $( \pm$ SD) 
Thus, the production of blueberry fruits remains a perspective goal, which by studying and promoting on a large scale the most valuable of blueberry, which is distinguished by the superior technology, organoleptic properties, with high productivity potential and long duration, early ripening, increased resistance to adverse environmental conditions, diseases and pests.

\section{CONCLUSIONS}

As a result of the researches carried out on the adaptability of blueberry studied in the cultivation conditions of the Republic of Moldova, it was found that:

- The climatic conditions are favorable, if the requirements of this species are met;

- Shows high resistance to frost, diseases and pests;

- Requires irrigation according to the needs of the plants;

- Budding takes place between 15-23 ${ }^{\text {rd }}$ March, flowering between 17-26 th April, and maturation between $25^{\text {th }}$ June- $06^{\text {th }}$ July depending on the climatic conditions of the year;

- The climatic conditions of the year influenced the quality indicators of blueberry fruits, so that in 2015 all studied cultivars recorded the highest values for the amount of accumulated dry matter (15.04\%), sugars - 7.74\%; Vitamin C - $19.80 \mathrm{mg} \%$ and the highest quality of fruits according to the sugar/acid coefficient (9.29).

\section{ACKNOWLEDGEMENTS}

The researches were carried out in the years 2018-2020 within the project - "State Program 20.80009.5107.22A" Development and modernization of sustainable and ecological technologies of fruit and shrubs species in the climate change conditions". We are grateful to all collaborators for the technical assistance provided in carrying out the project.

\section{REFERENCES}

1. Asănică A. (2017). Inovații în cultura arbuştilor fructiferi. Editura Total Publishing, Universitatea de Științe Agronomice și Medicină Veterinară: 35 p.

2. Cociu, V., and Oprea Şt. (1989). Metode de cercetare în ameliorarea plantelor pomicole. Editura Dacia: p. 2032.

3. Sumedrea D., IsacI., and Iancu M. (2014). Pomi, arbuști fructiferi, cãpșun - Ghid ethnic și economic. Editura Invel Multimedia: p.244-246.

4. Gradinaru G., and Istrate M. (2009). Pomicultura generală.: p. 484-490.

5. Mladin Gh., and Mladin P. (1992). Cultura arbuştilor fructiferi pe spaţii restrînse. Editura CERES: p. 88-91. 